\title{
Educational Neglect and Child Protection in Ontario
}

\author{
Joanna Harris, B.A., LL.B., LL.M.
}

Lawyer

York Region Children's Aid Society, Newmarket, Ontario

\begin{abstract}
Education is a basic human right, critical to the social and economic well-being of children and youth. It is so fundamental to a child's well-being that Ontario courts have repeatedly recognized that educational neglect is a stand-alone child protection concern justifying state intervention. Courts in Ontario acknowledge that educational neglect is also a significant indicator of greater neglect within the child's family. Education law, and child protection law, are remedies that should both be utilized to remedy educational neglect in a child's life.

Children involved with a child welfare system are vulnerable and often fail to achieve basic educational goals as a result of pre-existing neglect but also as a result of the system itself. Greater collaboration is needed between educators, social workers, and responsible ministries to ensure that vulnerable children's educational needs are met.
\end{abstract}

Keywords: Educational Neglect, Child Protection, Children in Care 


\section{Education is a Human Right}

Education is a core social and economic right that is recognized in the Universal Declaration of Human Rights (UDHR), ${ }^{1}$ which was adopted by the United Nations General Assembly and ratified by Canada in 1948. In particular, the right to education is set out in the UDHR as follows (art. 26):

(1) Everyone has the right to education. Education shall be free, at least in the elementary and fundamental stages. Elementary education shall be compulsory. Technical and professional education shall be made generally available and higher education shall be equally accessible to all on the basis of merit.

(2) Education shall be directed to the full development of the human personality and to the strengthening of respect for human rights and fundamental freedoms...

In 1989, the United Nations General Assembly adopted the Convention on the Rights of the Child, ${ }^{2}$ which was ratified by Canada in 1991. States that are parties to the Convention, including Canada, recognize the right of a child to education and agree to take measures to ensure children have access to education. ${ }^{3}$

\section{Children Involved with Child Welfare}

In Ontario, children do not receive their right to education equitably. For example, children involved with child welfare systems are likely to be at a significant disadvantage to others, given that their experiences are associated with, among other things, poor academic performance. ${ }^{4}$ Children and youth involved with the child welfare system, many of whom come from families who live in poverty and communities that have poor educational systems, and higher rates of crime, face systemic and multi-faceted barriers to receiving a high-quality education. ${ }^{5}$ According to the Ontario Association of Children's Aid Societies, only $44 \%$ of children in the care of children's aid societies are expected to graduate from high school, compared to $81 \%$ for their peers. ${ }^{6}$

In Ontario, there are approximately 16,500 youth in care of a children's aid society at any moment, and about 7,000 of those are living in extended society care (formerly referred to as 
Crown wards). ${ }^{7}$ Among those, Indigenous children and young people are vastly overrepresented in the child welfare systems in Ontario. ${ }^{8}$ The mistreatment of a child has a negative influence on educational outcome. ${ }^{9}$ Poor school attendance has become one of the strongest predictors of academic failure and permanent school dropout. Yet, academic achievement has been shown to be a critical protective factor against the development of mental health problems for children exposed to maltreatment and trauma. ${ }^{10}$

\section{The Education Act}

Ontario's Education Act ${ }^{11}$ states that a strong public education system is the foundation of a prosperous, caring and civil society. The purpose of education is to provide students with the opportunity to realize their potentials and develop into highly skilled, knowledgeable, and caring citizens who contribute to society.

Section 21 of Ontario's Education Act states that attendance at school is compulsory for children between the ages of 6 and $18 .{ }^{12}$ Section 21 (5) states that the parent or guardian shall cause a person to attend school, unless the person is at least 16 years old and has withdrawn from parent control. Pursuant to Section 30 (1), any parent who neglects or refuses to cause a person to attend school, who is required to attend, is guilty of an offence and, on conviction, is liable to pay a fine. In addition, a person required to attend school who refuses to attend or who is habitually absent from school is guilty of an offence. ${ }^{13}$

\section{The Child, Youth and Family Services Act}

Child protection legislation in Canada has as its purpose the protection, best interests, and well-being of children. The state will intervene into the lives of children and families when a child is in need of protection, which is defined by general categories of mistreatment, or risk of mistreatment, in each provincial or territorial statute. When the court finds that a child is in need of protection, the state can intervene to remedy the protection concern.

Child protection statues in New Brunswick (the Family Services Act) ${ }^{14}$ and Quebec (the Youth Protection Act $)^{15}$ specifically categorize educational neglect as basis for a finding that a child who may be in danger or in need of protection. Newfoundland's Child and Youth Care and 
Protection $A c t^{16}$ includes a category of "deprivation of cognitive stimulation" in the circumstances where a child is in need of protective intervention.

On June 1, 2017, the Ontario government enacted the Child, Youth and Family Services Act, $2017^{17}$ (CYFSA). The CYFSA does not explicitly list educational neglect or absenteeism from school as a protection concern and neither did its predecessor, the Child and Family

Services Act $^{18}$ (CFSA), which was promulgated in 1984. However, prior to that time, the Ontario Child Welfare Act included in the definition of a child in need of protection as "a child who without sufficient cause is habitually absent from home or school."19

\section{A Review of Select Ontario Cases Addressing Educational Neglect}

In $R v$. Jones ${ }^{20}$, Mr. Justice LaForest of the Supreme Court of Canada commented on the state's interest in the education of its citizens:

Whether one views it from an economic, social, cultural or civic point of view, the education of the young is critically important in our society. From an early period, the provinces have responded to this interest by developing schemes for compulsory education. Education is today a matter of prime concern to government everywhere. Activities in this area account for a very significant part of every provincial budget. Indeed, in modern society, education has far-reaching implications beyond the province, not only at the national, but at the international level.

Mr. Justice La Forest also cited the decision of the Supreme Court of the United States in Brown v Board of Education of Topeka: ${ }^{21}$

Today, education is perhaps the most important function of state and local governments. Compulsory school attendance laws and the great expenditures for education both demonstrate our recognition of the importance of education to our democratic society. It is required in the performance of our most basic public responsibilities, even service in the armed forces. It is the very foundation of good citizenship. Today it is a principal instrument in the awakening of the child to cultural values, in preparing him for later professional training, and helping him to 
adjust normally to his environment. In these days, it is doubtful that any child may reasonably be expected to succeed in life if he is denied the opportunity of an education.

Despite the absence of a specific category of educational neglect among the specific harms in the CYFSA, the courts in Ontario have held that the failure to provide a proper education constitutes risk of emotional harm and emotional harm to the child. ${ }^{22}$ In C.A.S. v. $M . S^{23}$, Justice Robertson recognized that "without an education, [the child] will be unable to meet his own economic future needs." In C.A.S. v. J.K.V. ${ }^{24}$, Justice Starr held that "[the child's] poor school attendance while in his mother's care threatened to undermine his social, emotional and educational development."

Moreover, courts have recognized that a proper education is important to an individual (who is greatly hindered in life without a proper education) and society (which needs an intelligent, well-informed society).

Courts in Ontario have recognized that when children are habitually absent from school or late for school, it is often a symptom of significant dysfunction or neglect in the family. ${ }^{25} \mathrm{~A}$ number of school changes and missed school days are evidence of ongoing instability in a parent's life and an inability to provide children with a stable home environment. ${ }^{26}$

In 2007, in the case of C.A.S. v. B.P. ${ }^{27}$, Justice Shaughnessy considered the issue of whether a home-schooling parent's failure to provide a satisfactory education, as set out in the Education Act, can also constitute a child protection concern. Justice Shaughnessy determined that neglect of education that either causes emotional harm, or risk thereof, may be dealt with under the CFSA ${ }^{28}$, which is the predecessor to the current legislation, provided that the children's aid society can relate it to a protection issue under the CFSA. The Court held that the state has a vested interest in the education of children ${ }^{29}$, the importance of educating children cannot be overstated in terms of the child's overall healthy development, and the protection of a child's best interest must take priority over the desires and interests of parents. ${ }^{30}$

In 2014, in the case of C.A.S. v. J.S. ${ }^{31}$, the issue was the Lev Tahor religious community's provision at home of education to children in their community by members of the community. In 
2011, the Lev Tahor community came into conflict with the local school board in Quebec because the children were not registered in school and the children were not being educated in accordance with the curriculum required by Quebec law. ${ }^{32}$ A court in Quebec had ordered the children's apprehension into foster care. ${ }^{33}$ In the middle of the night, the Lev Tahor community members relocated to Chatham, Ontario. ${ }^{34}$ A court in Ontario then decided that the Quebec order could not be enforced given that "the jurisdiction of any court in Canada with respect to child protection or child welfare matters ends at the borders of the province of that court." 35 Justice Templeton noted the "protection of a child from harm, where it becomes necessary to do so, is a basic tenet of our legal system" 36 and endorsed the decision of Justice Shaughnessy in C.A.S. v. B.P., in which he wrote, "[ $\mathrm{t}]$ he CFSA then is engaged where neglect of education becomes a child protection issue." 37

In 2019, the case of C.A.S. v. C.C. ${ }^{38}$ was primarily concerned with educational neglect. Justice Jain determined that the child's high rates of absenteeism and late attendance at school while in her mother's care put the child at risk of emotional harm and developmental delay. Justice Jain held that any child who is habitually absent or late from school without sufficient cause may be a child in need of protection. ${ }^{39}$

In 2019, in C.A.S. v. N.N. ${ }^{40}$, Justice Zisman held that a father placed his children at risk of emotional harm when he decided to enroll the children in French language school ${ }^{41}$, ignored the children's struggles and unhappiness in their French schools, and ignored their wishes about returning to their old school.

In contrast, in a 2015 case, C.A.S. v. M.R. ${ }^{42}$, Justice Murray determined that a child, who seldom attended school in the previous three years, would not be ordered to attend school on a full-time basis. Such an order could cause emotional damage given that the child had ongoing health problems and had previously been the subject of bullying. ${ }^{43}$ The mother had been facing prosecution under the Education Act for her child's absenteeism. ${ }^{44}$ Given the seriousness of the child's academic delay, Justice Murray accepted that the Mother's refusal to send him to school could be the basis for a protection finding in these circumstances however, they declined to order the child into full time school. ${ }^{45}$ 
In C.A.S. v. V.B. and M.B. ${ }^{46}$, Justice Chappel determined there were longstanding and persistent concerns regarding the parents' ability to ensure that the children's educational needs were consistently met. ${ }^{47}$ The children missed many days of school and, when they did attend, they were often late. ${ }^{48}$ The children were found to be significantly delayed in their verbal skills and the parents had not been engaging with the school to address the issues. ${ }^{49}$

In C.A.S. v. J.K.V. ${ }^{50}$, Justice Starr held that a child's significant number absences from school as well as frequent late arrivals, placed a child at risk likely to suffer emotional harm. ${ }^{51}$ There were numerous other protection concern at issue in this case as well.

Educational neglect is often recognized as a protection concern but is rarely the only cause for the state to intervene through child protection proceedings. There are usually other child protection concerns combined with the education neglect. ${ }^{52}$

\section{Combining the Remedies under the Education Act and the CYFSA}

Compulsory education law may be inadequate in motivating some parents to send their children to school and to meet the educational needs of their children. A primary problem of compulsory education law is that it focuses on parental inaction. However, to be effective and address the educational needs at issue, the focus must be on the child receiving an education. The focus of intervention is on ensuring that the child is receiving an adequate education and not punishing the parents or the child. To accomplish this laudable goal, the use of child protection law may be more effective than compulsory education laws.

Additionally, the Education Act lacks any enforcement power to ensure that a child's educational needs or best interests are being met. The CYFSA empowers children's aid societies to intervene when necessary. Using child protection law to protect children's interest in receiving an education is well supported by the cases in Ontario. In some circumstances, using child protection laws and compulsory education laws in unison to ensure proper education for children.

The paramount concern of child protection laws is to protect children from abuse and neglect. The immediate effects of educational neglect may not cause severe harm, but the best interests of a child are not viewed solely in immediate terms. The severity of educational neglect 
lies in the future harm that it causes. It can pose an insurmountable obstacle to a child's future. A child who lacks a fundamental educational background in areas such as basic reading or arithmetic is limited in his or her potential.

However, courts should intervene only if it will do more good than harm. This principle recognizes that an intervention might be harmful to a child ${ }^{53}$ and, even if it is not, the child is not guaranteed any better care if removed from the parent.

In C.A.S. v. V.F. ${ }^{54}$, the child was found to be in need of protection for various reasons including suffering from unaddressed learning difficulties that were impeding her education. ${ }^{55}$ Justice Cohen was highly critical of the months of delay by a children's aid society to put appropriate therapeutic and educational supports in place. ${ }^{56}$ The Court held:

It was the parents' responsibility, within their limited resources, to attend to their child's emotional health and intellectual development. They did not do so. The society became the child's temporary statutory parent. Its resources were incomparably greater. Yet the society allowed months to pass without attending to those very needs... It should not be necessary for this court to order the society to provide services that it is under a statutory duty to provide. ${ }^{57}$

\section{Increased Collaboration Between Educators, Social Workers, and Ministries}

Some promising collaborations between the Ministry of Children, Community and Social Services and the Ministry of Education have begun and further work remains to be done. ${ }^{58}$ Many school boards and societies have already developed positive, collaborative practices and relationships. These collaborations are promising because of the complex nature of addressing educational neglect and the difficulties children and youth may encounter interacting with many different systems, which can include the education system, child protection system, and even the criminal justice system.

\section{Conclusion}

Educational neglect is not only a concern for compulsory education law, but also a child protection concern that warrants state intervention. Courts in Ontario have recognized that it is a 
form of emotional neglect. Intervention is necessary, including the removal of children from their parents' care. However, children involved with the child welfare systems are vulnerable to ongoing education neglect and poor educational outcomes. While there are resources to help students, too often, young people are not aware of such supports. Greater collaboration between the child welfare workers and educators is key, as well as continued collaboration between ministries responsible for child welfare and education to ensure that the specific educational needs of children and youth involved with the child welfare system are being met.

\section{References}

Armfield J. M., Gnanamanickam, E., Nguyen, H. T., Doidge, J. C., Brown, D. S., Preen, D. B., \& Segal, L. (2020). School Absenteeism Associated With Child Protection System Involvement, Maltreatment Type, and Time in Out-of-Home Care. Child Maltreatment, 25(4). https://doi.org/10.1177/1077559520907682.

Baker v. Canada (Minister of Citizenship and Immigration), [1999] 2 S.C.R. 817.

Brown v. Board of Education of Topeka, 347 U.S. 483 (1954).

Butler, K. (2019). Youth in and from care and the Right to Education: Current Context and Recommendations. Retrieved from https://maytree.com/wpcontent/uploads/Youth_in_Care.pdf.

C.A.S. v. A.R./C.J./T.T., 2011 ONSC 7248 (CanLII).

C.A.S. v. B.P., 2007 CanLII 45905 (ON SC).

C.A.S. v. C.C., 2019 ONSC 4541 (CanLII).

C.A.S. v. C.L.C., 2011 CanLII 79383 (ON CJ).

C.A.S. v. C.V., 2009 CanLII 90644 (ON SC).

C.A.S. v. E.D., 2019 ONCJ 712 (CanLII).

C.A.S. v. E.U., 2014 ONCJ 299 (CanLII).

C.A.S. v. J.K.V., 2018 ONCJ 337 (CanLII).

C.A.S. v. J.S., 2014 ONSC 2352 (CanLII). 
C.A.S. v. K.(A.), 2007 ONCJ 735 (CanLII).

C.A.S. v. L.W., 2016 ONSC 3 (CanLII).

C.A.S. v. M.L., 2011 ONCJ 647 (CanLII).

C.A.S. v. M.M., 2016 ONCJ 374 (CanLII).

C.A.S. v. M.R., 2015 ONCJ 196 (CanLII).

C.A.S. v. M.S., 2005 CanLII 44177 (ON SC).

C.A.S. v. N.N., 2019 ONCJ 8 (CanLII).

C.A.S. v. V.B. and M.B, 2015 ONSC 4602 (CanLII).

C.A.S. v. V.F., 2003 CanLII 49834 (ON CJ).

den Dunnen, W. (2017). A Systemic Analysis of the Child Welfare System: Understanding the strengths and needs of in-home and out-of-home children and examining the role of foster child factors on the fostering experience. Retrieved from https://ruor.uottawa.ca/bitstream/10393/35671/5/den_Dunnen_Wendy_2017_thesis.pdf.

Hagborg, J. M., Berglund, K., \& Fahlke, C. (2018). Evidence for a relationship between child maltreatment and absenteeism among high-school students in Sweden. Child Abuse \& Neglect, 75, 41-49. https://doi.org/10.1016/j.chiabu.2017.08.027.

J.J.S. v P.P., 2020 ONSC 1038 (CanLII).

Nichols, N., Schwan, K., Gaetz, S., Redman, M., French, D., Kidd, S., O’Grady, B. (2017). Child Welfare and Youth Homelessness in Canada: A Proposal for Action. Toronto: Canadian Observatory on Homelessness Press. Retrieved from https:/homelesshub.ca/sites/default/files/ChildWelfare-PolicyBrief-final_0.pdf.

Ontario Association of Children's Aid Societies. (2010). Children's Well-Being: The Ontario Perspective, Child Welfare Report 2011. Retrieved from http://www.oacas.org/wpcontent/uploads/2015/09/11childwelfarereporteng.pdf.

Ontario Ministry of Children, Community and Social Services. (2015). Children and Youth at Risk. Retrieved from http://www.children.gov.on.ca/htdocs/English/about/EBB/2016/atrisk.aspx. 
Ontario Human Rights Commission. (2018). Interrupted Childhoods: Over-representation of Indigenous and Black Children in Ontario Child Welfare. Retrieved from http://www.ohrc.on.ca/en/interrupted-childhoods.

R. v. Jones, [1986] 2 S.C.R. 284.

Trivedi, S. (2019). The Harm of Child Removal. New York University Review of Law and Social Change 43, 523. Retrieved from https://scholarworks.law.ubalt.edu/all_fac/1085.

United Nations. (1948). Universal declaration of human rights. Retrieved from http://www.un.org/en/universal-declaration-human-rights/.

United Nations. (1989). United Nations Convention on the Rights of the Child. Retrieved from https://www.ohchr.org/en/professionalinterest/pages/crc.aspx.

Williams, S. (2008). Perspective of the Child in Custody and Access Decisions: Implementing a Best Interests and Rights of the Child Test. Canadian Bar Review, 86(3), 633.

\section{Notes}

1 United Nations. (1948). Universal declaration of human rights. Retrieved from http://www.un.org/en/universal-declaration-human-rights/.

${ }^{2}$ United Nations. (1989). United Nations Convention on the Rights of the Child. Retrieved from https://www.ohchr.org/en/professionalinterest/pages/crc.aspx.

${ }^{3}$ E.g., Williams, S. (2008). Perspective of the Child in Custody and Access Decisions: Implementing a Best Interests and Rights of the Child Test. Canadian Bar Review, 86(3), 633.; J.J.S. v P.P., 2020 ONSC 1038 (CanLII); and Baker v. Canada (Minister of Citizenship and Immigration), [1999] 2 S.C.R. 817.

${ }^{4}$ Nichols, N., Schwan, K., Gaetz, S., Redman, M., French, D., Kidd, S., O’Grady, B. (2017). Child Welfare and Youth Homelessness in Canada: A Proposal for Action. Toronto: Canadian Observatory on Homelessness Press. Retrieved from https://homelesshub.ca/sites/default/files/ChildWelfare-PolicyBrief-final_0.pdf.

5 den Dunnen, W. (2017). A Systemic Analysis of the Child Welfare System: Understanding the strengths and needs of in-home and out-of-home children and examining the role of foster child factors on the fostering experience. Retrieved from https://ruor.uottawa.ca/bitstream/10393/35671/5/den_Dunnen_Wendy_2017 thesis.pdf.

${ }^{6}$ Ontario Association of Children's Aid Societies. (2010). Children's Well-Being: The Ontario Perspective, Child Welfare Report 2011. Retrieved from http://www.oacas.org/wpcontent/uploads/2015/09/11childwelfarereporteng.pdf.

${ }^{7}$ Ontario Ministry of Children, Community and Social Services. (2015). Children and Youth at Risk. Retrieved from http://www.children.gov.on.ca/htdocs/English/about/EBB/2016/atrisk.aspx. 
${ }^{8}$ Ontario Human Rights Commission. (2018). Interrupted Childhoods: Over-representation of Indigenous and Black Children in Ontario Child Welfare. Retrieved from http://www.ohrc.on.ca/en/interrupted-childhoods.

${ }^{9}$ Armfield J. M., Gnanamanickam, E., Nguyen, H. T., Doidge, J. C., Brown, D. S., Preen, D. B., \& Segal, L. (2020). School Absenteeism Associated With Child Protection System Involvement, Maltreatment Type, and Time in Out-of-Home Care. Child Maltreatment, 25(4). https://doi.org/10.1177/1077559520907682.

${ }^{10}$ Hagborg, J. M., Berglund, K., \& Fahlke, C. (2018). Evidence for a relationship between child maltreatment and absenteeism among high-school students in Sweden. Child Abuse \& Neglect, 75, 41-49. https://doi.org/10.1016/j.chiabu.2017.08.027.

${ }^{11}$ Education Act, R.S.O. 1990, c. E.2 [hereinafter "Education Act"].

${ }^{12}$ Ibid., at s. 21.

${ }^{13}$ Ibid., at s. 30(5).

${ }^{14}$ Family Services Act, SNB 1980, c F2.2, s. 31(1)(k) states:

31(1) The security or development of a child may be in danger when:

(k) the child is in the care of a person who neglects or refuses to ensure that the child attends school; or

${ }^{15}$ Youth Protection Act, CQLR c P-34.1, Section 38(b) iii. states:

(b) "neglect" refers to

(1) a situation in which the child's parents or the person having custody of the child do not meet the child's basic needs,

iii. failing to provide the child with the appropriate supervision or support, or failing to take the necessary steps to ensure that the child receives a proper education and, if applicable, that he attends school as required under the Education Act (chapter I-13.3) or any other applicable legislation;

${ }^{16}$ Child and Youth Care and Protection Act, SNL2010 Chapter C-12, s. 10(3)(d) of states that:

10. (1) A child is in need of protective intervention where the child

(c) is being, or is at risk of being, emotionally harmed by the parent's conduct and there are reasonable grounds to believe that the emotional harm suffered by the child, or that may be suffered by the child, results from the actions, failure to act or pattern of neglect on the part of the child's parent;

10 (3) For the purposes of paragraph (1)(c), parental conduct or living situations that may lead to emotional harm or risk of emotional harm to the child may include

(d) deprivation of cognitive stimulation;

${ }^{17}$ Child, Youth and Family Services Act, 2017, S.O. 2017, c. 14, Sched. 1.

${ }^{18}$ Child and Family Services Act, R.S.O. 1990, c. C-11 much like the majority of provinces and all of territories in Canada for example: Alberta - Child, Youth and Family Enhancement Act, RSA 2000, c C-12, British Columbia - Child, Family and Community Service Act, RSBC 1996, c 46; Manitoba - The Child and Family Services Act SM 1985-86, c. 8, Nunavut - Child and Family Services Act, SNWT (Nu) 1997, c 13, Northwest Territories - Child and Family Services 
Act, S.N.W.T. 1997,c.13, Nova Scotia - Children and Family Services Act, SNS 1990, c 5Prince Edward Island - Child Protection Act, RSPEI 1988, c C-5.1, Saskatchewan - Child and Family Services Act, SS 1989-90, c C-7.2, and Yukon - Child and Family Services Act, SY 2008, c 1.

${ }^{19}$ Child Welfare Act, R.S.O. 1980, c. 66, at s. 19(1)(b)(viii).

${ }^{20}$ R. v. Jones, [1986] 2 S.C.R.284.

${ }^{21}$ Brown v Board of Education of Topeka, 347 U.S. 483 (1954).

${ }^{22}$ C.A.S. v. M.S., 2005 CanLII 44177 (ON SC) at para. 5, where Justice Robertson recognized that "without an education, he will be unable to meet his own economic future needs"; and C.A.S. v. J.K.V., 2018 ONCJ 337 (CanLII) at para. 114, where Justice Starr held that "the child's poor school attendance while in his mother's care threatened to undermine his social, emotional and education development."

${ }^{23}$ C.A.S. v. M.S., 2005 CanLII 44177 (ON SC).

${ }^{24}$ C.A.S. v. J.K.V., 2018 ONCJ 337 (CanLII) at para. 114.

${ }^{25}$ C.A.S. v. C.C., 2019 ONSC 4541 (CanLII), at para. 36.

${ }^{26}$ C.A.S. v. M.L., 2011 ONCJ 647 (CanLII) at para. 100.

${ }^{27}$ C.A.S. v. B.P., 2007 CanLII 45905 (ON SC).

${ }^{28}$ Child and Family Services Act, R.S.O. 1990, c. C-11.

${ }^{29}$ C.A.S. v. B.P., 2007 CanLII 45905 (ON SC) at para. 40.

${ }^{30}$ C.A.S. v. B.P., 2007 CanLII 45905 (ON SC) at para. 43.

${ }^{31}$ C.A.S. v. J.S., 2014 ONSC 2352 (CanLII).

${ }^{32}$ Ibid., at para. 13.

${ }^{33}$ Ibid., at para. 66.

${ }^{34}$ Ibid., at para. 43.

${ }^{35}$ Ibid., at para. 91.

${ }^{36}$ Ibid., at para. 168.

${ }^{37}$ C.A.S. v. B.P., 2007 CanLII 45905 (ON SC) at para. 33.

${ }^{38}$ C.A.S. v. C.C., 2019 ONSC 4541 (CanLII).

39 Ibid., at para. 37.

${ }^{40}$ C.A.S. v. N.N., 2019 ONCJ 8 (CanLII).

${ }^{41}$ Ibid., at para. 234.

${ }^{42}$ C.A.S. v. M.R., 2015 ONCJ 196 (CanLII).

${ }^{43}$ C.A.S. v. M.R., 2015 ONCJ 196 (CanLII), at para. 20.

${ }^{44}$ C.A.S. v. M.R., 2015 ONCJ 196 (CanLII), at para. 14 (19).

45 Ibid., at para. 18.

${ }^{46}$ C.A.S. v. V.B. and M.B, 2015 ONSC 4602 (CanLII).

${ }^{47}$ Ibid., at para. 115.

${ }^{48}$ Ibid., at para. 116.

${ }^{49}$ Ibid., at para. 117-119.

${ }^{50}$ C.A.S. v. J.K.V., 2018 ONCJ 337 (CanLII).

${ }^{51}$ Ibid., at para. 111.

${ }^{52}$ For example: C.A.S. v. K.(A.), 2007 ONCJ 735 (CanLII), C.A.S. v. V.B. and M.B, 2015 ONSC 4602 (CanLII), C.A.S. v. J.K.V., 2018 ONCJ 337 (CanLII), C.A.S. v. C.V., 2009 CanLII 90644 (ON SC), C.A.S. v. C.L.C., 2011 CanLII 79383 (ON CJ), C.A.S. v. M.L., 2011 ONCJ 647 (CanLII), C.A.S. v. A.R./C.J./T.T., 2011 ONSC 7248 (CanLII), C.A.S. v. M.M., 2016 ONCJ 374 
(CanLII), C.A.S. v. E.D., 2019 ONCJ 712 (CanLII), C.A.S. v. E.U., 2014 ONCJ 299 (CanLII), and C.A.S. v. L.W., 2016 ONSC 3 (CanLII).

${ }^{53}$ Trivedi, S. (2019). The Harm of Child Removal. New York University Review of Law and Social Change 43, 523. Retrieved from https://scholarworks.law.ubalt.edu/all_fac/1085.

${ }_{55}^{54}$ C.A.S. v. V.F., 2003 CanLII 49834 (ON CJ).

${ }^{55} \mathrm{Ibid}$., at para. 8.

${ }^{56} \mathrm{Ibid}$., at paras. 12 and 18.

${ }_{58}^{57} \mathrm{Ibid}$., at para. 18.

${ }^{58}$ Butler, K. (2019). Youth in and from care and the Right to Education: Current Context and Recommendations. Retrieved from https://maytree.com/wp-content/uploads/Youth_in_Care.pdf. 